\title{
Impact of Feedback Timing on Teaching Competence of Pre-Service English Teachers
}

\author{
Yoonhee Choe \\ Department of English Education, Chongshin University, Seoul, Korea \\ Received May 11, 2019; Revised October 21, 2019; Accepted November 14, 2019
}

Copyright $\bigcirc 2019$ by authors, all rights reserved. Authors agree that this article remains permanently open access under the terms of the Creative Commons Attribution License 4.0 International License

\begin{abstract}
Various types of feedback provided to pre-service English teachers have been reported to enhance their teaching competence. Many previous studies have focused on the effects of feedback methods, including explicit and implicit feedback, but only a few studies have investigated the impact of feedback timing. Therefore, this study investigates the impact of feedback timing on pre-service English teachers' teaching competence. Forty-six pre-service English teachers participated in the study and were asked to perform microteaching twice. After the microteaching sessions, delayed and immediate feedback were given. After the feedback, survey and focus group interviews were conducted on a voluntary basis. The results showed that different pre-service English teachers differently perceived the impact of feedback timing on their teaching competence and their affective aspects such as anxiety and motivation. This study provides pedagogical implications for pre-service English teacher educators and program developers.
\end{abstract}

Keywords Feedback Timing, Delayed Feedback, Immediate Feedback, Teaching Competence, Pre-Service English Teachers

\section{Introduction}

Since a decade ago, global communication has become widely common, and education of English as a global language has been emphasized upon. In particular, in English as a foreign language (EFL) countries such as Korea, China, Taiwan, and Japan, English education has been a primary educational concern (Jeon \& Choe, 2018; Al Zoubi 2018). To address this concern, many studies on effective English education have been conducted. Most of these studies have been focused on enhancing EFL or English as a second language (ESL) students' language development, but relatively few studies have been focused on improving teachers' English language proficiency and teaching competence (Choe, 2014; 2016; Abdulrasheed 2017).

In the field of English teacher education, focused on English teachers' teaching competence and English language proficiency, many of the previous studies have investigated the beliefs and teaching practices of in-service teachers, rather than pre-service teachers. To improve English education, teacher training curriculum and programs should be carefully planned and designed for not only in-service teachers but also pre-service English teachers, because many aspects of English education in the classroom depend on both in- and pre-service English teachers' teaching competence. Specifically, in- and pre-service English teachers' competence in instruction in English is very crucial.

To improve pre-service teachers' teaching competence, some studies have examined which teaching and feedback methods are more effective. Choe (2014); Dierker,et.al (2018) investigated the effects of one-on-one conference with an instructor on the "teacher talk" of pre-service English teachers. Moreover, implicit and explicit feedback are still controversial issues in terms of their effects (Crooks \& Chaudron, 2001; Altunkaya \& Ates 2018; Georgantopoulos,Poutos \& Eriotis 018). However, little research has been conducted on feedback timing. Feedback timing can be divided into two types: immediate and delayed. Immediate feedback means giving feedback right after the teaching session, and delayed feedback means giving feedback a certain period after the teaching session (Aldulaimi \& Abdeldayem 2018; Chima \& Kasim 2018).

Therefore, this study attempts to investigate the effects of feedback timing on the teaching competence and the affective aspects including anxiety, motivation, and confidence of pre-service English teachers.

The research questions are: 1) How do pre-service Korean teachers of English perceive immediate and delayed corrective feedback on the improvement of their 
teaching competence? 2) How do pre-service Korean teachers of English perceive immediate and delayed corrective feedback on their affective aspects (e.g., anxiety and self-confidence) as student teachers?

\section{Theoretical Background and Literature Review}

Teacher training institutions and colleges have tried to design their curriculum for enhancing pre-service English teachers' teaching competence based on second language acquisition (SLA) and other pedagogical theories. In the courses for pre-service teachers, they are trained to improve their teaching skills. Giving and receiving feedback is necessary for successful course design. Feedback types can be categorized on the basis of three parameters: method, timing, and provider of feedback.

\section{Method of feedback (implicit vs. explicit)}

In feedback-related research, some scholars have made distinction between implicit and explicit feedback. Some have argued that correcting errors overtly might be more effective for learners. Conversely, others have reported that implicit feedback such as recast is better for learners' affective aspects even though it is effective only in $20-25 \%$ of the cases (Crooks \& Chaudron, 2001).

\section{Timing of feedback (immediate vs. delayed)}

The timing of feedback has been considered an important factor influencing L2 acquisition (Nakata, 2015). Most studies that examined the empirical effects of feedback timing compared two types of feedback: immediate and delayed (Li, Zhu, \& Ellis, 2016; Yasaei, 2016; Zadkhast, 2017). Some studies have argued the superiority of delayed feedback over immediate feedback due to the "delay-retention effect" (Nakata, 2015; Metcalfe, Kornell, \& Finn, 2009; Vahdany and Gerivani, 2016; Jayakumar, 2016; Verma, Stoffova and Zoltán, 2018; Kweka and Ndibalema, 2018; Owagbemi, 2018). The delay-retention effect can be explained by the "distributed practice effect" (Nakata, 2015). The distributed practice effect can be accounted for by the assumption that when learners have longer spacing time, they will have better retention (Metcalfe, Kornell, \& Finn, 2009). For example, when learners are given feedback immediately after they make errors, they might get confused between their errors and the correct answers. However, when learners are given delayed feedback, they are less likely to be confused and more likely to learn more effectively (Butler, Karpicke, \& Roediger, 2007; Mory, 2004; Halder and Chandra, 2012; Dumbu, 2014; Pan, 2014; Esia-Donkoh, Amihere and Addison, 2015; Vahdany, and Gerivani, 2016; Wijayanto and Sumarwan, 2016; Masciantonio and Berger, 2018; Al-Fadley., Al-Holy and Al-Adwani, 2018;). In contrast to these studies, others have argued that immediate feedback has more advantages than delayed feedback for learners' learning and retention. These studies employed various empirical settings; therefore, the results might have been inconsistent.

\section{Methods}

\section{Participants}

The participants were 46 pre-service English teachers who were majoring in English language education at a university located in Seoul, Korea. Table 1 shows the demographic information of the participants.

Table 1. Demographic Information of Participants

\begin{tabular}{|c|c|c|}
\hline & Categories & $\mathrm{N}$ \\
\hline \multirow{2}{*}{ Gender } & Male & 14 \\
\hline & Female & 28 \\
\hline \multirow{2}{*}{ Majors } & English language education & 37 \\
\hline & Education-related & 5 \\
\hline
\end{tabular}

To examine to what degree the participants improved their teaching competence, the participants' microteaching was video-recorded after the first and second sessions. All

\section{Research Procedures (Data Collection and Analysis)}

The participants took the course named "Theories and Methodologies of English Teaching," which is one of the compulsory courses offered to pre-service Korean teachers of English by the Ministry of Education in Korea. Pre-service teachers were asked to perform microteaching twice. First microteaching was performed after the midterm, and the participants were provided individual feedback one week later (delayed feedback). After the delayed feedback, they performed the second microteaching based on the first feedback. After the second microteaching, they were given immediate feedback, right after their microteaching. All their microteaching sessions were video-recorded and stored in a Web storage, named $N$ Cloud.

Before the delayed feedback session, the pre-service teachers were asked to reflect their microteaching and find their weaknesses for one week. During the delayed feedback session, the instructor and pre-service teachers shared what they found to be improved and interacted on how to improve their teaching in the designated place. So the content of feedback was only to the instructor and the pre-service teachers. In contrast, during the immediate feedback session, the instructor gave direct feedback and comments to the pre-service teacher right after their microteaching with a whole class. So, the feedback and comments were all shared with the whole class. 


\section{Research Instruments}

\section{Survey Questionnaires}

In order to investigate to what extent the participants perceived the effects of feedback types depending on the timing (immediate vs. delayed) on the improvement of their teaching competence, survey questionnaires were developed. The total number of items were 18. The participants were asked to respond from 0 to five scores to each item respectively. Besides, the participants were asked to write their own perceptions and reasons for the items.

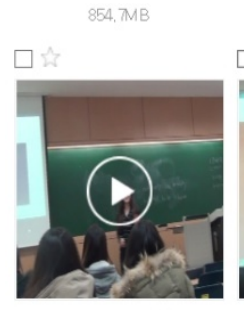

Jungyoun2,MTS

10e1.6ME

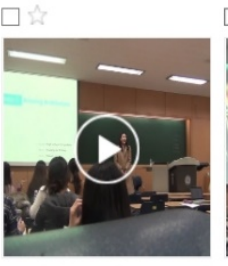

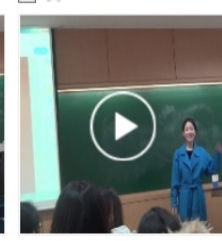

Sanga2,MTS $857.9 M B$

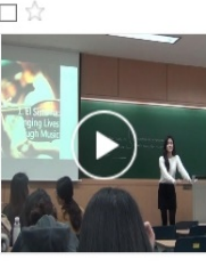

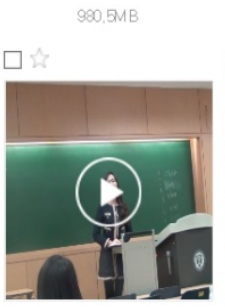

Yuna2,MTS
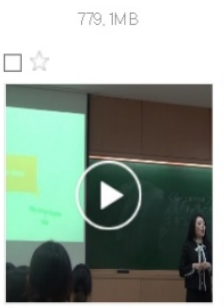

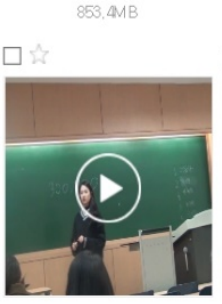

Seoyoung2MTS
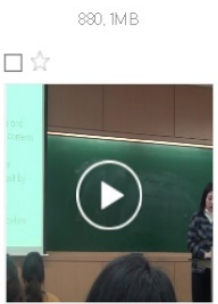

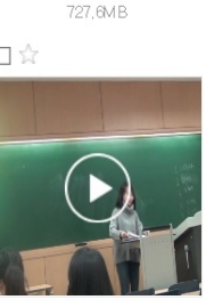

Haewon2MTS
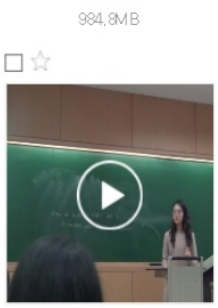

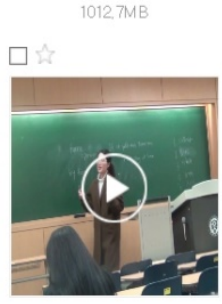

Jeongw on 2. MTS
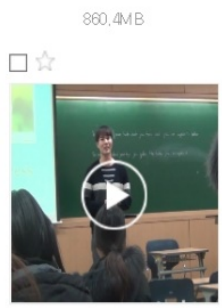

$995,5 \mathrm{MB}$

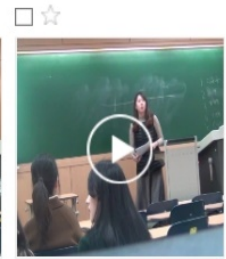

Miiin 2,MTS

$841.5 \mathrm{MB}$

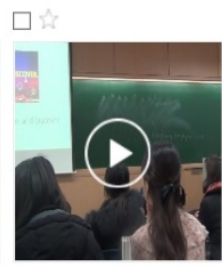

Figure 1. Storage and Retrieval of Participant Videos

Figure 1 shows that the participants' microteaching sessions were video-recorded and the movie clips were stored in a web hard. The participants were asked to analyze their teaching practices by observing their video recordings.

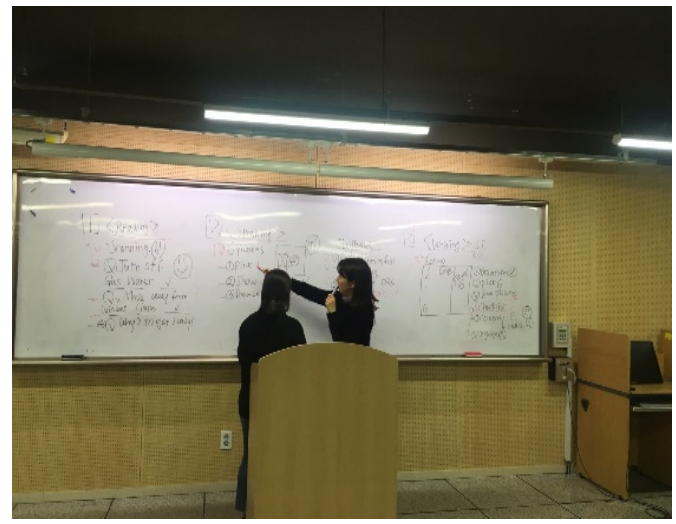

Immediate feedback right after the microteaching

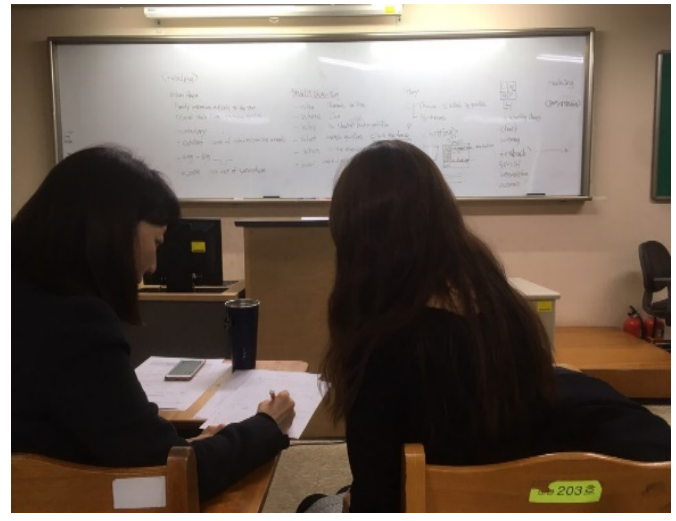

Delayed feedback one week later

Figure 2. Immediate and Delayed Feedback

Figure 2 shows immediate and delayed feedback being given to the participants. The left panel shows the instructor giving feedback right after the microteaching, pointing weaknesses and strengths. On the other hand, the right panel shows the instructor giving delayed feedback individually a week after the participant's teaching session. 

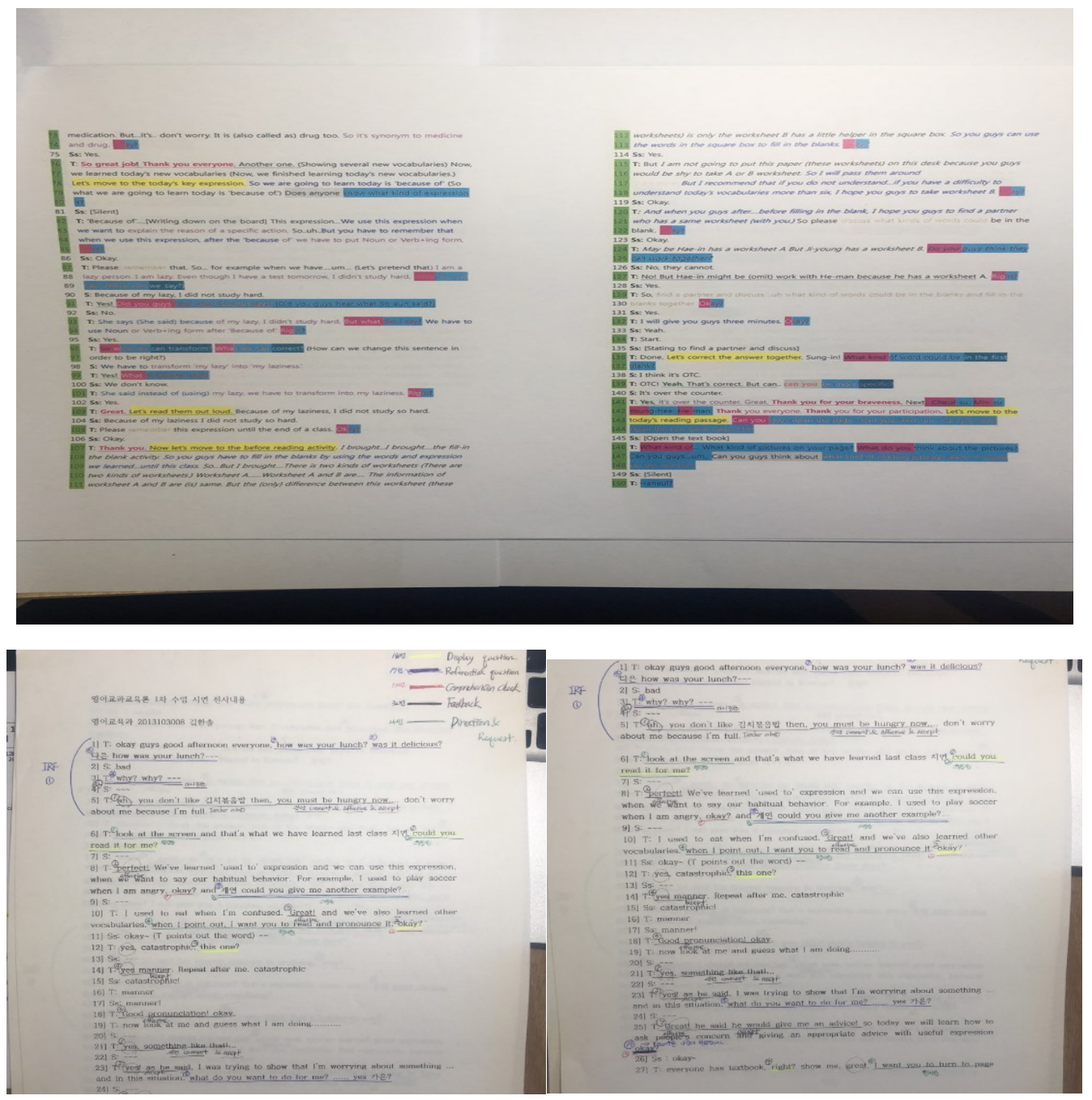

Figure 3. Non-feedback Activity (Transcript Analysis)

Figure 3 shows one of the non-feedback activities - transcript analysis based on the "teacher talk" frame. The participants' views on different feedback timings and non-feedback activities were examined via survey analysis and focus group interviews.

\section{Results and Discussion}

The first research question was on the pre-service teachers' perception of feedback timing on their teaching competence. As shown in Table 2, most of the mean scores in the questionnaires were above 3.8, indicating the participants responded positively to all questions. Out of the items, the instructor's immediate feedback received the highest score (4.59). Moreover, the mean score for immediate feedback was 4.24, which was higher than that for delayed feedback.

Clearly, the participants preferred immediate feedback over delayed feedback, perceiving the former to be more effective than the latter. In addition, the participants perceived the instructor's individual feedback the best among all types of feedback. The results of this study are similar to those reported in previous literature that explicit feedback is more effective than implicit feedback (Li, Zhu, \& Ellis, 2016). The participants were adult pre-service English teachers who were eager to develop their teaching skills. They really wanted to know their strengths and weaknesses right after their microteaching sessions. However, some participants, who were relatively shy and less confident in their teaching, preferred delayed feedback to immediate feedback because they felt less anxious in the delayed feedback sessions and had relatively more time to interact with the instructor about their teaching. Eventually, it seemed to lead to more development of their teaching competence to some of the less confident students. Additionally, during the delayed 
session, instructor provided not only weaknesses but also strengths and encouragements, the participants were reported to become more motivated. Thus, in terms of affective aspects such as anxiety and confidence, participants felt delayed feedback was more advantageous in enhancing their teaching competence. These results are in the similar line with the previous research which reported the effects of low anxiety on second language learning (Choe, 2014).

Table 2. Descriptive Statistics on Feedback Types participants' teaching competence in general)

Instructor's individual feedback
(The degree to which the instructor's individual feedback affects the improvement of the participants' teaching competence)

$\begin{array}{lllll}42 & 3 & 5.00 & 4.59 & .706\end{array}$

.703

(1)

Instructor's delayed (a week after) feedback

(The degree to which the instructor's delayed feedback affects the $\begin{array}{llll}42 & 2 & 5.00 & 3.86\end{array}$

1.049 improvement of the participants' teaching competence)

Instructor's immediate feedback

(The degree to which the instructor's immediate feedback affects the $\begin{array}{llll}42 & 2 & 5.00 & 4.24\end{array}$ .878 improvement of the participants' teaching competence)

Instructor's written feedback

(The degree to which the instructor's written feedback affects the improvement $\quad \begin{array}{lllll}42 & 2 & 5.00 & 4.07\end{array}$ of the participants' teaching competence)

Peers' written feedback

(The degree to which peers' written feedback affects the improvement of the $\quad \begin{array}{lllll}42 & 2 & 5.00 & 3.90\end{array}$ participants' teaching competence)

Peers' written feedback on other peers' teaching competence

$\begin{array}{lllll}\text { (The degree to which peers' written feedback affects the improvement of the } & 42 & 2 & 5.00 & 3.94\end{array}$

1.045 other peers' teaching competence)

Feedback based on TEE evaluation chart

$\begin{array}{lllll}\text { (The degree to which written feedback based on TEE evaluation chart affects } & 42 & 2 & 5.00 & 4.10\end{array}$ the improvement of the participants' teaching competence)
.973 
Table 3. Descriptive Statistics on Non-feedback Activities

\begin{tabular}{|c|c|c|c|c|c|}
\hline Effects of non-feedback activities on teaching competence & $\mathrm{N}$ & Min & Max & M & SD \\
\hline $\begin{array}{l}\text { Writing Self-reflection } \\
\text { (The degree to which self-reflection affect the improvement of the participants' own teaching competence) }\end{array}$ & 42 & 3 & 5.00 & 4.51 & .840 \\
\hline $\begin{array}{l}\text { Writing transcript } \\
\text { (The degree to which writing transcript on microteaching affect the improvement of the participants' own teaching } \\
\text { competence) }\end{array}$ & 42 & 2 & 5.00 & 4.45 & .861 \\
\hline $\begin{array}{l}\text { Observation of peers' microteaching } \\
\text { (The degree to which observing peers' microteaching affect the improvement of the participants' own teaching } \\
\text { competence) }\end{array}$ & 42 & 2 & 5.00 & 4.26 & .828 \\
\hline $\begin{array}{l}\text { Cognitively challenging } \\
\text { (The degree to which writing transcripts on microteaching is cognitively challenging to the participants) }\end{array}$ & 42 & 2 & 5.00 & 2.64 & 1.358 \\
\hline $\begin{array}{l}\text { Analyzing transcript on learning theories } \\
\text { (The degree to which analyzing transcript based on SLA theories } \\
\text { affect the improvement of the participants' own teaching competence) }\end{array}$ & 42 & 3 & 5.00 & 4.12 & .942 \\
\hline
\end{tabular}

\section{Conclusion}

This study aimed to examine effective feedback timing for pre-service English teachers' teaching competence. The participants perceived immediate feedback to be more advantageous than delayed feedback even though delayed feedback offered them a less anxious environment. Some of the less confident participants reported the advantages of delayed feedback in terms of low affective filter, but most the participants preferred immediate feedback to delayed feedback. This result is in line with previous literature that explicit direct feedback is more effective for correcting learners' errors (e.g., Li, Zhu, \& Ellis, 2016). This study contributes to current research related to effective timing of feedback for pre-service English teachers. However, it has some limitations. All the participants were Korean pre-service English teachers, so the findings of this study cannot be generalized. Also, this study just examined the perception of the participants on the impact of feedback types. Their teaching practices after receiving two different types of feedback were not empirically compared. Thus, the effects of feedback timing on pre-service teachers' teaching competence were not investigated. Further research which compares experimental and control groups using statistical analysis will provide more pedagogical implications for developing effective English teacher training courses and programs in EFL settings.

\section{Acknowledgments}

I feel special gratitude to the participants for their enthusiastic support and participation in this research. I am also very grateful to the anonymous reviewers for their appropriate and constructive suggestions. Some preliminary findings of the study were presented at the workshop administered by Chongshin Center for Teaching and Learning in 2017.

\section{REFERENCES}

[1] Abdulrasheed, B. (2017). Causality between government expenditure and government revenue in Nigeria. Asian Journal of Economics and Empirical Research, 4(2), 91-98.

[2] Akuegwu, B. A., \& Nwi-ue, F. D. (2017). Providing Academic Leadership in Universities in Cross River State, Nigeria: Assessment of Departmental Heads' Effectiveness. Asian Journal of Education and Training, 3(1), 18-24.

[3] Al Zoubi, S. M. (2018). The Significance of Error Analysis in Written Production: A Case Study of Ajloun National University Students. International Journal of English Language and Literature Studies, 7(4), 150-159.

[4] Aldulaimi, S. H., \& Abdeldayem, M. M. (2018). The Economic Value of Time in Arab Culture: New Evidence using Zimbardo Time Perspective Inventory (ZTPI). Humanities, 3(1), 63-72.

[5] Al-Fadley, A., Al-Holy, A., \& Al-Adwani, A. (2018). Teacher Perception of Parents Involvement in their Children's Literacy and their Reading Instructions in Kuwait EFL Primary School Classrooms. International Journal of Education and Practice, 6(3), 120-133.

[6] Altunkaya, H., \& Ates, A. (2018). Sources of Reading Anxiety among the Learners of Turkish as a Foreign Language. Asian Journal of Education and Training, 4(3), 161-169.

[7] Butler, A. C., Karpicke, J. D. \& Roediger, H. L. (2007). The effect of type and timing of feedback on learning from multiple-choice tests. Journal of Experimental Psychology: Applied, 13(4), 273-281.

[8] Chima, P., \& Kasim, U. (2018). Public-private partnership as a strategy for e-governance funding in Africa: The gains and the pains. International Journal of Public Policy and Administration Research, 5(2), 37-47.

[9] Choe, Y. (2014). The effects of one-on-one consultations on pre-service secondary English teachers' classroom discourse skills, The Journal of Mirae English Language and Literature, 19(3), Aug. 251-270.

[10] Choe, Y. (2016). Effects of scaffolded video analysis on pre-service English teachers' classroom interactions and 
professional development. International Journal of Multimedia and Ubiquitous Engineering, 11(3), 283-290.

[11] Crooks, G. \& Chaudron, C. (2001). Guidelines for language classroom instruction. In M. Celce-Murcia, Teaching English as a Second or Foreign Language. 3rd Edition. 2942.

[12] Dierker, L., Evia, J. R., Singer-Freeman, K., Woods, K., Zupkus, J., Arnholt, A., \& Rose, J. (2018). Project-Based Learning in Introductory Statistics: Comparing Course Experiences and Predicting Positive Outcomes for Students from Diverse Educational Settings. International Journal of Educational Technology and Learning, 3(2), $52-64$.

[13] Dumbu, E. (2014). Promoting entrepreneurship through open and distance education in Zimbabwe. A case study of the Zimbabwe Open University students at Masvingo Regional Campus. International Journal of Business, Economics and Management, 1(6), 101-114.

[14] Esia-Donkoh, K., Amihere, A. K., \& Addison, A. K. (2015). Assessment of Student Internship Programme By 2013/2014 Final Year Students of the Department of Basic Education, University of Education, Winneba, Ghana. Humanities and Social Sciences Letters, 3(2), 105-120.

[15] Georgantopoulos, A. G., Poutos, E. I., \& Eriotis, N. (2018). Recent Developments and Trends in Accounting Information Systems. Journal of Accounting, Business and Finance Research, 3(1), 1-9.

[16] Halder, S. N., \& Chandra, S. (2012). Users'Attitudes towards Institutional Repository in Jadavpur University: A Critical Study. International Journal of Management and Sustainability, 1(2), 45-52.

[17] Jayakumar, R. (2016). Opinion of the University Teachers towards Educational Television Programmes. American Journal of Education and Learning, 1(1), 45-52.

[18] Jeon, J. \& Choe, Y. (2018). Cram schools and English language education in East Asian contexts. In John I. Liontas, (Ed.), TESOL Encyclopedia of English Language Teaching (pp. 475-489). NJ: Wiley Blackwell.

[19] Kweka, K. H., \& Ndibalema, P. (2018). Constraints Hindering Adoption of ICT in Government Secondary Schools in Tanzania: The Case of Hanang District. International Journal of Educational Technology and Learning, 4(2), 46-57.

[20] Li, S., Zhu, Y., \& Ellis, R. (2016). The effects of the timing of corrective feedback on the acquisition of a new linguistic structure. The Modern Language Journal, 100(1), 276-295.

[21] Masciantonio, T. A., \& Berger, P. D. (2018). Is Alumni Salary an Appropriate Metric for University Marketers? Journal of Social Economics Research, 5(1), 1-9.

[22] Metcalfe, J., Kornell, N., \& Finn, B. (2009). Delayed versus immediate feedback in children's and adults' vocabulary. Memory \& Cognition, 37, 1077-1087.

[23] Mory, E. H. (2004). Feedback research revisited. In D. H. Jonassen (Ed.), Handbook of research on educational communications and technology, 745-783.

[24] Nakata, T. (2015). Effects of feedback timing on second language vocabulary learning: Does delaying feedback increase learning? Language Teaching Research, 19, 416434.

[25] Owagbemi, G. O. (2018). Assessing the Relocation of Adekunle Ajasin University to Akokoland on Transportation System and Rural Development in Ondo State. Humanities and Social Sciences Letters, 6(2), 51-58.

[26] Pan, C. Y. (2014). Effects of Reciprocal Peer-Questioning Instruction on EFL College Students English Reading Comprehension. International Journal of English Language and Literature Studies, 3(3), 190-209.

[27] Vahdany, F., \& Gerivani, L. (2016). An analysis of the English language needs of medical students and general practitioners: A case study of Guilan University of Medical Sciences. International Journal of English Language and Literature Studies, 5(2), 104-110.

[28] Verma, C., Stoffova, V., \& Zoltán, I. (2018). Perception Difference of Indian Students towards Information and Communication Technology in Context of University Affiliation. Asian Journal of Contemporary Education, 2(1), 36-42.

[29] Wijayanto, H., \& Sumarwan, U. (2016). Analysis of the factors influencing Bogor Senior High School student choice in choosing Bogor Agricultural University (Indonesia) for further study. Journal of Education and e-Learning Research, 3(3), 87-97.

[30] Yasaei, H. (2016). The effect of immediate vs. delayed oral corrective feedback on the writing accuracy of Iranian intermediate EFL learners. Theory and Practice in Language Studies, 6, Sep. 1780-1790.

[31] Zadkhast, M. (2017). The impact of immediate and delayed corrective feedback on Iranian EFL learners' willingness to communicate. International Journal of Applied Linguistics \& English Literature, 6, Nov. 28-39. 